\title{
PITFALLS OF HOUSING REDISTRIBUTION
}

\section{GARL F. HOROWITZ $†$}

Advocates of metropolitan-wide income and racial egalitarianism have been taking some hits lately. For once, the political juggernaut to reduce income and racial differences across community lines is running into detours instead of creating them.

For example, late last summer a joint Senate and House Conference Committee overseeing spending by the U.S. Department of Housing and Urban Development (HUD) shelved a \$149.1 million fiscal 1995 appropriation for the Moving to Opportunity (MTO) program. $^{1}$ MTO, modeled on HUD's Gautreaux Demonstration program, is intended to enable low-income inner-city recipients of Section 8 vouchers and certificates to move to communities with relatively little poverty concentration. ${ }^{2}$ Anthony Downs, senior fellow with the Brookings Institution, characterized the action as "part of the hysterical reaction by conservatives against having lowincome people moving into their communities."

If that were not enough, Republicans last November won a majority in the House and Senate for the first time in forty years. ${ }^{4}$ GOP leaders have made it clear that they intend to reduce the size and reach of the federal government by scaling back or eliminating agencies repeatedly plagued by inefficiency, waste, and corruption. Owing largely to this Congressional realignment, the Clinton Administration came close to recommending that Congress abolish HUD, an agency not unknown for its share of corruption. ${ }^{5}$ In response, HUD Secretary Henry Cisneros and key aides quickly

† Washington Correspondent, Investor's Business Daily.

I Instrumental in the action was Maryland Democratic Senator Barbara Mikulski, who had "strong reservations" about the program and questioned its administrative oversight. Ann Mariano, Hill Panel Halts Plan to Move Poor Families, WASH. PosT, Sept. 3, 1994, at E1.

2 See id.

${ }^{3} I d$. at E6.

${ }^{1}$ Republicans did hold a majority in the Senate after the elections in 1980, 1982 , and 1984. The elections of 1994 represented the first time since 1952 that the GOP gained a majority in both houses. See Dan Balz, GOP Captures Congress: Party Controls Both Houses for First Time Since '50s, WASH. POST, Nov. 9, 1994, at A1.

${ }^{5}$ Even sources sympathetic to HUD's mission have harshly evaluated the agency. See, e.g., National ACAdEMY of PUb. AdMIN., Renewing HUD: A LONG-TerM AGENDA FOR EFFECTIVE PERFORMANCE at ix (1994) (noting problems with political leadership, budget, and program overload). The two-year study was mandated by Congress. 
mapped out a reorganization plan to save their department. ${ }^{6}$ The proposal calls for consolidating sixty major HUD programs into three performance-based funds by fiscal year 1998, converting subsidies for public housing into portable rent certificates, ${ }^{7}$ and transforming the Federal Housing Administration (FHA) into a government-owned corporation resembling a modern insurance company more than a bureaucracy. ${ }^{8}$

Finally, the Federal Reserve last fall released a study on over 200,000 FHA loans. They found that black borrowers exhibited significantly higher default rates in both urban and suburban locations and that losses due to default were greater on loans to black borrowers. ${ }^{9}$ Such results might give pause to Justice Department prosecutors, convinced that banks are denying blacks and other minorities fair access to mortgage credit and thus must be coerced into signing costly consent decrees.

Predictably, panic and anger are setting in. At a speech before the National Press Club on February 14, 1995, Cisneros remarked, "today we hear voices spewing forth the flawed logic of Social Darwinism, calling for government's withdrawal from the housing arena, rejecting America's long tradition of steady, forward progress in favor of retrenchment and regression." ${ }^{10}$ The egalitarians' fear of losing political ground is what has set the context for this Law Review Symposium. Two of its more thoughtful and moderate expositors, Michael Schill and Susan Wachter, have issued what amounts to a cautious endorsement of those expressing such fears. ${ }^{11}$ That may be as good as libertarians can hope for at a

${ }^{6}$ See U.S. DeP'T OF Hous. \& URBan Dev., A Place to Live IS THE Place to START: A STATEMENT OF PRINCIPLES FOR CHANGING HUD TO MEET AMERICA'S HOUSING AND COMMUNITY PRIORITIES (1995).

${ }^{7}$ If adopted, this move might render the MTO program irrelevant because public housing tenants would have the option to use tenant assistance in the same portable manner that MTO participants do.

${ }^{8}$ The FHA has been part of HUD since the department initially went into operation in early 1966. The FHA was created in 1934 to insure lenders of home mortgages against the risk of default.

${ }^{\circ}$ See James A. Berkovec et al., federal Reserve Sys., Discrimination, DefaUlT, AND LOSS IN FHA MORTGAGE LENDING (1994). For a discussion of the report, see Paul C. Roberts, Deflating the Mortgage Bias Balloons, WASH. TIMES, Feb. 16,1995 , at A18.

${ }^{10}$ Secretary Henry G. Cisneros, U.S. Dep't of Hous. \& Urban Dev., Speech at the National Press Club 3 (Feb. 14, 1995) [hereinafter Cisneros Speech] (transcript on file with author).

"See Michael H. Schill \& Susan M. Wachter, The Spatial Bias of Federal Housing Law and Policy: Concentrated Poverty in Urban America, 143 U. PA. L. REV. 1285 (1995). 
forum where the necessity of a pursuit of social equality by the state is a foregone conclusion. If the authors fail to grasp some larger philosophical and political issues, they do offer valuable insights as to why command-and-control housing policies so often go astray. Whether through public housing development and management, subsidized private construction, mortgage insurance, or mandated community reinvestment, the federal government inadvertently has reinforced ghettoization, or, as the authors term it, "spatial bias." The agglomeration of low-income persons in turn has accelerated crime rates, welfare dependency, drug abuse, and illiteracy in innercity life. Without the presence of employed adult male role models, gangs and other unsavory demimonde have become proxy mentors for much of a whole generation of young urban blacks. ${ }^{13}$ While the authors overestimate the extent to which the concentration of poverty actually causes this to happen, at least they exhibit an understanding that discrimination against blacks may explain a lot less about inner-city life than commonly imagined.

\section{UNINTENDED CONSEQUENCES}

In a number of housing policy areas, the authors are on strong ground, such as their analysis of the public housing program. The architects of the United States Housing Act of $1937,{ }^{14}$ originally a ladder of mobility for the working poor, hardly envisioned public housing projects as becoming places for large concentrations of a nonworking and often dysfunctional underclass. Schill and Wachter note that the roots of much of the problem began in the 1949 housing legislation, when Congress set income limits requiring that tenants leave a project if their income exceeded five times their rent, a requirement aggravated by the granting of first priority for admission to displacees of slum clearance programs. ${ }^{15}$ Over time, these policies helped trigger a financial crisis in larger housing authorities that led to the Brooke Amendment of 1969, limiting rent to twenty-five percent of tenant income (raised early in the Reagan

${ }^{12} I d$. at 1285.

is See Douglas S. Massey \& Nancy A. Denton, American Apartheid: SEGREGation AND THE MAKING OF THE UNDERCLASS 165-81 (1993) (discussing the culture of segregation); WILLIAM J. WILSON, THE TRULY DISADVANTAGED: THE INNER CITY, THE UNDERCLASS, AND PUBLIC POLICY 20-62 (1987) (discussing social change and social dislocation in the inner city).

${ }^{14}$ See Schill \& Wachter, supra note 11, at 1291.

${ }^{15}$ See id. at 1292. 
years to thirty percent). ${ }^{16}$ Despite the 1974 Housing and Community Development Act's call to "avoid concentrations of low-income and deprived families with serious social problems," the authors note that Congress in 1981 mandated that practically all public housing residents, especially those in new projects, be of "very low" income, and eased these quotas only a few notches in the CranstonGonzalez legislation of $1990 .{ }^{17}$

The authors also note that the effects of the one-for-one replacement rule requiring that a PHA create a new unit for every one demolished has been "pernicious for many inner-city communi-

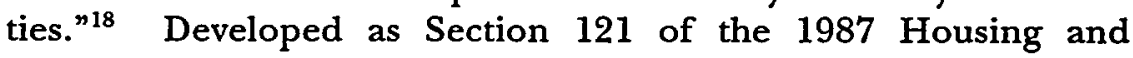
Community Development Act by Democrat Representatives Henry Gonzalez (Texas) and Barney Frank (Massachusetts) to "protect" the public housing stock, this provision has done little more than prevent the removal of public housing eyesores; even Secretary Cisneros, at least by implication, wants to repeal it. ${ }^{19}$ One hopes he is willing to cross swords with public housing tenant activists who are likely to sue (and too often have, successfully) to prevent the razing of decrepit projects. For a long time, the courts have played a role in eviscerating standards in public housing anyway. By ruling on behalf of plaintiffs attempting to loosen admission and residence requirements, judges have given public housing tenants insulation from expectations of reasonable behavior, and thus from eviction laws, unavailable to tenants in privately-owned dwellings. ${ }^{20}$

The authors might have mentioned an additional, more recent, source of decay in public housing-the giving of top priority to "the homeless" and "the disabled" for residence. These groups have suc-

${ }^{16}$ See id. at 1296.

${ }^{17}$ See id. at 1295 n.44. The Omnibus Budget Reconciliation Act of 1981 mandated that $95 \%$ of all occupants in newly-constructed units have very low incomes (less than $50 \%$ of the area median income). See Pub. L. No. 97-35, § 323, 95 Stat. 357, 404-05 (codified as amended at 42 U.S.C. $\$ 1437 \mathrm{n}(1988)$ ). The 1990 Cranston-Gonzalez National Affordable Housing Act reduced this quota to $85 \%$. See Pub. L. No. 101$625, \S 511,104$ Stat. 4079, 4194 (1990) (codified at 42 U.S.C. $\$ 1437 n$ (Supp. V 1993)). For a brief overview of the history of the public housing program, see RACHEL G. BRATT, REBUILdiNG A Low-INCOME Housing POLICY 53-85 (1989).

${ }^{18}$ Schill \& Wachter, supra note 11 , at 1314.

${ }^{19}$ See U.S. DEP'T OF HOUS. \& URBAN DEV., supra note 6, at 24 (discussing HUD's recent progress in demolishing some of the worst public housing in the nation); see also Guy Gugliotta, HUD Proposal Could Raze More Projects, WASH. POST, Feb. 8, 1995, at $\mathrm{A}$ ], A8 (noting that "HUD attempted to loosen [the] regulatory logjam" hindering the tearing down of public housing projects).

${ }^{20}$ See J.S. Fuerst \& Roy Petty, Due Process-How Much Is Enough?, PUB. INTEREST, Spring 1985, at 96, 101. 
ceeded in crowding out admission slots ordinarily reserved for more responsible persons. The behavior of residents in these two categories has contributed to the breakdown in many projects. For dysfunctional welfare families, a homeless shelter often is a waiting room to the front of the line for public housing. ${ }^{21}$ A 1992 General Accounting Office report revealed the quagmire that resulted from late-1980s HUD regulations giving the nonelderly disabled entry into projects intended for the elderly. ${ }^{22}$ While public housing, which by its nature lacks market incentives, cannot be made to "work" in a manner analogous to that of the market, at least it has offered a reasonably stable living environment where elementary notions of reciprocity between landlord and tenant are in force. Absent even that, there is nowhere for a project to go but down.

The authors do a credible job in analyzing Federal Housing Administration mortgage insurance programs, although they overstate the role of the FHA in promoting racial segregation. To be sure, the agency initially had recommended racially-restrictive covenants, but it dropped the practice in $1950 .^{23}$ Although for decades the FHA did focus the bulk of its attention on suburban communities, this had less to do with a whites-only policy than with the reality that whites had the incomes to move to suburbs and the space that suburbs offered (that is, the filtering process). ${ }^{24}$ If the FHA has contributed toward isolation of the poor, it has done so most of all in attempting to compensate for racial bias, whether deliberate or not. The Section 235 program, created in 1968 as a

21 See Alice S. Baum \& Donald W. BuRnes, a Nation in Denial: The Truth ABOUT HOMELESSNESS 74-76, 127-28 (1993) (noting that government housing policies give preference to homeless families over other families for subsidized housing); Randall K. Filer, What Really Causes Family Homelessness?, CrTY J., Autumn 1990, at 3140.

22 See U.S. Gen. Accounting Office, Public Housing: Housing Persons with MENTAL DISABILITIES WITH THE ELDERLY (1992). According to a questionnaire that the GAO conducted with housing authority managers, more than three in $\mathbf{1 0}$ of the nonelderly tenants were causing moderate to serious problems for other tenants and PHA management and staff, as opposed to about one in 15 elderly tenants. Moreover, the problems of the nonelderly mentally "disabled" took longer to resolve. See id. at 19.

${ }^{23}$ See MASSEY \& DENTON, supra note 13, at 54.

${ }^{24}$ See IRVING Welfeld, Where We LIVE: A SOCIAL HISTORY OF AMERICAN Housinc 81-103 (1988); John C. Weicher, Private Production: Has the Rising Tide Lifted All Boats?, in HOUSING AMERICA's POOR 53-57 (Peter D. Salins ed., 1987) (describing the filtering process and finding that "though there is not a great deal of empirical evidence to substantiate the rising tide hypothesis, nearly all the evidence that does exist supports it"). 
way to cast aside basic mortgage underwriting standards for largely black, low-income, first-time buyers, was a disaster by reason of its very abandonment of standards. ${ }^{25}$ The FHA's involvement in risky multifamily properties loans, moreover, has resulted in a massive pileup of privately-built apartment projects in assignment or foreclosure. ${ }^{26}$

The most pleasant surprise of Schill and Wachter's article is the finding that the Community Reinvestment Act (CRA) may be doing a disservice to its intended beneficiaries. ${ }^{27}$ The CRA, enacted in 1977 as part of a campaign by a network of community activists bent on scapegoating the financial community for urban decline, was meant, after all, to discourage disinvestment. Depository institutions, we were told (and have been told since with unceasing regularity), were singling out homeowners and would-be homeowners in low-income neighborhoods for excessive denials of loan applications, often because the borrower or the area (or both) were black. ${ }^{28}$ In the name of fairness, lenders have been forced to adjust alleged mismatches between assets and liabilities, with federal regulators on the lookout for geographic and racial disparities. ${ }^{29}$ Lenders, as well as borrowers, one might add, are paying for the paperwork: James Chessen, chief economist for the American Bankers Association, estimates the CRA's annual compliance tab at $\$ 2$ billion, about $20 \%$ of all federal bank regulatory costs. ${ }^{30}$ Despite its voluminous requirements, some members of Congress,

${ }^{25}$ For a brief, cogent analysis of why $\$ 235$ failed, see IRVING WELFELD, HUD SCANDAIS: Howling HEAdLINES AND SileNT FIASCOES 29-37 (1992).

${ }^{26}$ See Hamilton Sec. Group, INC., U.S. DeP'T OF HOUS. \& URBan Dev., Multifamily MORTGage Sales: General Information Package 6 (1994). As of August 1994, the inventory of FHA's mortgages in assignment (that is, in receivership) included 2341 multifamily mortgages with an unpaid principal balance of more than $\$ 7$ billion. These accounted for some 350,000 apartment dwellings. See id.

${ }^{27}$ See Schill \& Wachter, supra note 11, at 1286.

${ }^{28}$ See Allen J. Fishbein, The Ongoing Experiment with "Regulation from Below": Expanded Reporting Requirements for HMDA and CRA, 3 HOUSING POL'Y DEBATE 601, 605-06 (1992) (discussing studies finding substantial loan disparities).

${ }^{29}$ These regulators are the Federal Home Loan Bank Board (now the Office of Thrift Supervision), the Comptroller of the Currency, the Federal Deposit Insurance Corporation, and the Federal Reserve Board. These agencies have the power to reject a depository institution's application for a charter, a branch office, or deposit insurance, if it fails to get a satisfactory community rating. See Vern McKinley, Community Reinvestment Act: Ensuring Credit Adequacy or Enforcing Credit Allocation?, 4 REGULATION 25 (1994).

so See Carl Horowitz, Making Loans by the Numbers? New HUD Initiative May Create Lending Quotas, INVESTOR'S BUS. DAILY, Apr. 27, 1994, at 1, 2. 
like Representative Joseph P. Kennedy II of Massachusetts, have pressured regulators to grade banks and thrifts more harshly. ${ }^{31}$

Schill and Wachter's analysis implicitly says to Kennedy and similar critics, "Not so fast!" for the CRA may be inadvertently creating concentrations of low-income populations. The authors' test of this hypothesis, using a data subset from the Boston Federal Reserve study on mortgage bias, ${ }^{32}$ leads to the conclusion that an average low-income person applying for a loan in a predominantly nonpoor neighborhood is almost three times as likely to be rejected than if he or she had applied in a largely poor neighborhood. ${ }^{33}$ Although the authors admit that the data may not be conclusive, their analysis suggests that the CRA, by pressuring lenders into making loans to less than creditworthy borrowers in low-income neighborhoods, may be contributing to higher than normal default rates-and social instability.

\section{MisPlaced ACTIVISM}

Schill and Wachter have argued persuasively that federal housing initiatives may exhibit unseen defects, and rarely more so than in the kinds of initiatives meant to increase affordability for the poorest households. Unfortunately, they have drawn some unsound conclusions from their analysis, maintaining that the need for federal activism is greater than ever, only with a primary focus on "deconcentrating" the poor. ${ }^{34}$ It is here where the authors reveal unmistakably collectivist moorings and an all too conventional wish list.

The federal government's main order of business, argue the authors, ought to be rooting out racially discriminatory housing practices, whether deliberate or not, to encourage suburbanization. Schill and Wachter call, among other things, for HUD to file complaints, as the 1988 Fair Housing Amendments allow for, and not simply to hear them. They advocate more paired-adult undercover operations of the sort conducted in 1989 by a University of Syracuse-Urban Institute research team for HUD in twenty-five metropolitan areas. ${ }^{35}$ They call, like Anthony Downs and Peter

${ }^{31}$ See McKinley, supra note 29 , at 27.

${ }^{32}$ See Alicia H. MUNNell ET AL., MORTGage LENDING IN BOSTON: INTERPRETING HMDA DATA (Federal Reserve Bank of Boston Working Paper No. 92-7, 1992).

${ }^{33}$ See Schill \& Wachter, supra note 11, at 1327.

${ }^{34}$ See id. at 1328-41.

${ }^{95}$ See JOHN YINGER eT AL., U.S. DEP'T of Hous. \& URBAN DEV., Housing 
Salins, ${ }^{36}$ for less stringent land-use regulation-a commendable recommendation to be sure, but with that holy grail, the balanced socioeconomic mix, as the ulterior goal. ${ }^{37}$ Schill and Wachter also advocate expanding the use of Section 8 vouchers and certificates, first, by issuing more of them, and second, by increasing their portability and subsidy levels, so as to be more usable in suburban rental housing. ${ }^{38}$ They are hardly the only ones to call for such measures, ${ }^{39}$ but their critique is not stronger for it.

The authors apparently believe that in this, the age of telephones, faxes, radios, televisions, newspapers, and magazines, that isolation and concentration are responsible for the putative lack of economic opportunity for inner-city blacks. Although the notion of an "isolated" city or city neighborhood may be difficult to fathom, let us concede that there is a substantial body of research indicating that environment influences the life chances of the poor-that is, that a move to the suburbs may result for many urban blacks in a significantly, although not necessarily overwhelmingly, better life. ${ }^{40}$ Even with that in mind, at least two major considerations ought to be weighed before embarking on a crash program of spatial deconcentration.

First, by paying people to leave urban for suburban neighbor-

DISCRIMINATION STUDY: INCIDENCE OF DISCRIMINATION AND VARIATIONS IN DISCRIMINATORY BEHAVIOR at $x$ (1991). Studies such as these might legally qualify as entrapment.

${ }^{36}$ See ANThony Downs, Rental Housinc IN The 1980s, at 190-92 (1983); Peter Salins, Correcting New York's Housing Mistakes, CrTY J., Spring 1992, at 59-69.

${ }^{37}$ There are some quite legitimate reasons for opposing subsidized suburban construction as a way of housing the poor and some relatively untapped ways of using vacant inner-city land to achieve this purpose. See Howard Husock, Mocking the Middle Class: The Perverse Effects of Housing Subsidies, POL'Y REV., Spring 1991, at 65, 68-69 (describing successful subsidized construction programs in low-income, urban neighborhoods).

${ }^{38}$ See Schill \& Wachter, supra note 11, at 1336-39.

${ }^{39}$ See INTERWOven Destinies: Cities and the Nation (Henry G. Cisneros ed., 1993); MASSEY \& DENTON, supra note 13, at 231; Anthony Downs, Policy Directions Concerning Racial Discrimination in U.S. Housing Markets, 3 HOUSING POL'Y DEBATE, 685, 685-745 (1992); George C. Galster, Research on Discrimination in Housing and Mortgage Markets: Assessment and Future Directions, 3 HOUSING POL'Y DEBATE, 639, 639-83 (1992).

40 See MASSEY \& DENTON, supra note 13, at 177 (noting that by "confining large numbers of black people to an environment within which failure is endemic, ... segregation has helped to create a nihilistic and violent counterculture"); Dennis P. Hogan \& Evelyn M. Kitagawa, The Impact of Social Status, Family Structure, and Neighborhood on the Fertility of Black Adolescents, 90 AM. J. Soc. 825, 852 (1985) (blaming "high risk social environments" for an increased incidence of teen pregnancy). 
hoods, the federal government would be rendering the older neighborhoods even further mired in the conditions that prompted the exodus. An MTO-style program, like its Gautreaux predecessor, for programmatic and public-relations purposes, would have to engage in "cream-skimming," getting the least dysfunctional urban poor to participate. Left out of the lottery, and remaining in the older neighborhoods, would be the very sorts of people that have made many of these areas unlivable. The "urban crisis" actually would grow more pronounced.

Second, advocates of such a strategy, at least as a rhetorical exercise, should make a list of all the things that they see as making urban neighborhoods disadvantageous in comparison to suburban neighborhoods. Suppose that they included on the list such obvious candidates as violent crime, drug trafficking, drug addiction, poor schooling, welfare dependency, and vandalism. Is there not one of these things that cannot be ameliorated either by curbing the welfare state, whose tab for all levels of government reached almost $\$ 325$ billion in fiscal year $1993,{ }^{41}$ or by reprimanding the sorts of wrongdoers who make zones of enterprise into zones of fear?

Keep in mind that an "underclass" neighborhood, even one getting worse, does not necessarily consist entirely or even mainly of the kinds of people we would call underclass. ${ }^{42}$ Even in the worst neighborhoods, there are seeds of encouragement, the sorts of things that suburbs supposedly offer in far greater abundance. Before we throw up our hands and consign cities to the ashes, let us remember that there is much in them that can be made to work, for the poor and nonpoor alike, and need not involve enormous public expenditures or coercion. ${ }^{43}$ By removing the pernicious dis-

${ }^{11}$ See Hearings Before the Subcomm. on Human Resources of the House Comm. on Ways and Means, Fed. Document Clearing House Cong. TestimonY, Apr. 9, 1994, available in LEXIS, Leghis Library, Cngtst File (testimony of Robert Rector). Rector, a senior policy analyst on poverty and welfare issues for the Heritage Foundation, has calculated from dozens of household-means-tested and other programs that, even adjusting for inflation, antipoverty spending was less than $\$ 40$ billion at the onset of the War on Poverty when it was launched 30 years ago. Moreover, welfare spending rose during the Reagan years. See id.

12 See generally Ronald B. Mincy, Paradoxes IN BLACK EConomic Progress: INCOMES, FAMILIES, AND THE UNDERCLASS (Urban Institute Working Paper, 1989); Ronald B. Mincy \& Susan J. Wiener, The Underclass in the 1980s: Changing CONCEPT, CONSTANT REALITY (Urban Institute Draft Research Paper, 1993).

ts See Neal R. Peirce et al., Crtistates: How Urban America Can Prosper in A COMPETITIVE WORLD 291-325 (1993) (discussing guideposts for improving America's citistates). 
incentives to improvement of the lot of the poor, crime and welfare dependency foremost, government would be doing the urban poor-and suburbs-a better turn than subsidizing an exodus out of cities. It is no longer sufficient to say that the welfare state needs more funding but with a new focus; its supporters made such an excuse when cumulative antipoverty spending was but a fraction of what it is today. What is required is a recognition that the welfare state itself, even with a proper "focus," may be heavily contributing to the kinds of behavioral poverty that typify the underclass. Decades ago, when material conditions were quite inferior to those of today, and for all income levels, there was little talk of an underclass crisis.

Schill and Wachter's assumptions are grounded in William Julius Wilson's book The Truly Disadvantaged. ${ }^{44}$ Indeed, it is difficult to assess their article without in some measure reiterating, and refuting, Wilson's 1987 opus. Wilson, a sophisticated observer of the black urban underclass, understood that poverty is not simply a lack of income or material comforts, but also the product of years of learned behavior from family members, neighborhood authority figures, and peers. When a person, particularly a child, is constantly exposed to the destructive behavioral influences that make and keep people poor, that person is likely to internalize it as "normal," in the absence of intervention by adults operating in mentoring roles. ${ }^{45}$ Conservatives, Wilson noted, have become enamored of this cultureof-poverty thesis, making its augmentation with a more realistic welfare-state liberalism all the more imperative. ${ }^{46}$

The culture of the present-day inner city, Wilson avers, can be attributed to deliberately racially discriminatory practices that brought blacks in large numbers from rural areas to cities and restricted them to certain neighborhoods upon arrival. ${ }^{47}$ Yet this is only part of the story. For despite discrimination in job and housing markets, a black middle-class developed. So long as there was an abundance of local teachers, coaches, clergy, small business owners, as well as two-parent families to guide black children, it was possible for blacks to develop the social skills and time horizon necessary for success in adulthood. Unfortunately, as prejudice and discrimination partially dissipated in the decades after World War

\footnotetext{
44 WILSON, supra note 13.

${ }^{45}$ See id. at 56-57.

${ }^{46} \mathrm{See} i d$. at 5 .

${ }^{47}$ See id. at 13-14.
} 
II, the black urban middle-class left the cities. Minus the necessary compensatory federal aid, urban decay was inevitable, argued Wilson. ${ }^{48}$ Worse yet for the left-behinds, the kinds of industries traditionally drawing upon labor pools of unskilled and semi-skilled workers also had left town, leaving all too many black men tempted by life choices commonly associated with the underclass. "Today's ghetto neighborhoods," wrote Wilson, "are populated almost exclusively by the most disadvantaged segments of the black urban community, that heterogenous grouping of families and individuals who are outside the mainstream of the American occupational system. ${ }^{\text {n49 }}$

Public policy, he believed, needed an aggressive and visible federal hand. Through a variety of ways, government could provide a better geographic match between residence and workplace and also expose at-risk children to healthy socializing forces. To win the War on Poverty required "a far more comprehensive program of economic and social reform than what Americans have usually regarded as appropriate or desirable[,] . . . a radicalism that neither Democratic nor Republican parties have as yet been realistic enough to propose. ${ }^{50}$ Policymakers would have to shift their focus toward universal means-tested entitlements in job training, education, and housing, and away from styles of racial entitlement and political confrontation endemic to the 1960s. To do otherwise would be to bring down the very welfare-state edifice that Wilson had sought to expand. ${ }^{51}$

Wilson's arguments assume that human action results from blind, impersonal, historical forces beyond the ken of the individual, and not from recognizable motives. It is as if the pursuit of a life of crime, especially in and around inner-city public housing projects, rather than one of work, is not an act of volition and that it does not adversely affect the vitality of urban life. ${ }^{52}$ For Wilson, "isolation" and "concentration" serve as master explanations for all

${ }^{18}$ See id. at 151-59.

49 Id. at 7-8.

${ }^{50} \mathrm{Id}$. at 139.

${ }^{51}$ See id. at 163-64.

${ }^{52}$ Although crime is merely one source of neighborhood decline and neighborhoods can retain vitality despite crime, see RICHARD P. TAUB ET AL., PATHS OF NEIGHBorhood ChANGE: RACE AND CRIME IN URBAN AMERICA 14 (1984), it is also evident from research that crime all too frequently is an effective destroyer of neighborhoods. See generally WeSLEY G. SkOgan, DisORder AND DECLINE: CRIME AND THE SPIRAL OF DECAY IN AMERICAN NEIGHBORHOODS (1990). 
kinds of destructive behavior. Wilson's attribution of the overall shift in low-wage manufacturing industries from city to suburb to greater technological sophistication, moreover, seems difficult to reconcile with his desire for competitiveness in U.S. industry. Yet for all the book's questionable logic, it has defined the contours of contemporary urban policy debate as few works have. ${ }^{53}$

This is the intellectual pedigree of Schill and Wachter. They put a premium on creating more inducements to poor households relocating in communities where there are few other poor households. In this way, the deleterious realities of underclass life ought to dissolve into these larger middle-class and working-class communities. ${ }^{54}$ Like James Rosenbaum's, ${ }^{55}$ their faith in suburbia's capacity for immunizing people to social dysfunctions is nearly limitless. This is why they recommend a vast expansion of the Moving to Opportunity program. Never mind that the program, like any that uses Section 8 assistance, is costly; ${ }^{56}$ that low-income households have the capacity to export pathology into suburbanstyle communities, and not just be changed by them; ${ }^{57}$ or that public funds could be put to better use by punishing street criminals that have made once livable urban neighborhoods into outposts of barbarism. Suburbanites ought to recognize, as the conventional wisdom would have it, that their fortunes rise or fall with those of the inner city-their destinies are "interwoven," to use Secretary

${ }^{53}$ For a liberal critique similar to Wilson's, but ultimately more satisfying, see ChristopHer JeNCKS, Rethinking SOCIAL POLICY: RACE, POVERTY, AND THE UNDERCLASS (1992).

${ }^{54}$ Reducing or eliminating outright suburban political jurisdictions would make resistance to such experiments in income-mixing less potent. See DAVID RUSK, CrTIES WITHOUT SUBURBS 111-16 (1993). Rusk's book has gotten an enthusiastic response from welfare-state liberals. See Mickey Kaus, City Limits: TRB-Abolishing Suburbs, NEw RePublic, May 3, 1993, at 6 (suggesting that "Clinton and Gore" have tried to use some of the ideas contained in Cities Without Suburbs).

${ }^{55}$ See James E. Rosenbaum, Black Pioneers-Do Their Moves to the Suburbs Increase Economic Opportunity for Mothers and Children?, 2 HOUSING POL'Y DEBATE 1I79, 11791213 (1992).

${ }^{56}$ The current per-household five-year authorization level for a voucher or a certificate is around $\$ 35,000$, a figure allowing for local administrative costs and future rent inflation. Although this is not necessarily the actual program cost, and although participants can and do drop out before the initial five-year expiration, this can be an expensive proposition in high-cost rental market areas.

${ }^{57}$ See James Bovard, Suburban Guerrilla, AM. SPECTATOR, Sept. 1994, at 26, 26-32 (criticizing HUD Secretary Henry Cisneros's plan to, among other things, "relocate poor people away from 'poverty communities' or 'racially concentrated neighborhoods"). 
Cisneros's term..$^{58}$ Thus, residents and businesses in suburbs "owe" their urban brethren a debt. In the end, it is the Kerner Commission report that inspires the authors. For Schill and Wachter, economic, educational, and other forms of inequality among races are evidence that the Old Despotism remains the chief obstacle to the good metropolitan community-all the better to tighten the screws of the New Despotism.

\section{DESPOTS: Old AND NeW}

Let us now define our terms. In America, the Old Despotism, or what remains of it, is the collection of customs, habits, attitudes, and laws that once prevailed in, but was not limited to, Southern states. Even where not avowedly racist, it relegated black existence to caste status, enforcing that status through legal and extralegal means. Old Despots routinely invoked "states' rights" to deny basic liberties to blacks. ${ }^{59}$ It was petty, mean, and unconstitutional, but its very localism allowed its victims to "vote with their feet." As Nicholas Lemann, among others, has chronicled, that is exactly what many Southern blacks did after World War II-move northward into large cities. ${ }^{60}$ Old Despots prided themselves (and still do) on resistance to, not reliance upon, the federal government. As the Old Despotism in the mid-1960s was quickly discarded as official policy at all levels of government, its passing, regrettably, did not result in a libertarian, color-blind society, but instead in the New Despotism. Civil rights activists and their allies operated on the assumption that white racism, especially the "institutional" kind, presumably written into zoning ordinances and mortgage lending criteria, remained as pervasive as ever and thus required preferential treatment for blacks in schooling, jobs, housing, and credit. ${ }^{61}$ Indeed, the historical injuries done to blacks alone necessitated some form of action along these lines. The ultimate solution allowed no escape from one state to another because the federal government wielded the big stick. Those resisting these reparations,

${ }^{58}$ See generally INTERWOVEN DESTINIES: CITIES AND THE NATION, supra note 39.

${ }^{59}$ See Clint Bolick, Grassroots Tyranny: The Limits of FEderalism 13-92 (1993).

${ }^{60}$ See Nicholas Lemann, The Promised land: The Great Black Migration AND How IT CHANGed AMERICA 70-71 (1991) (noting that during periods in the 1950 s "2,200 black people were moving to Chicago every week").

${ }^{61}$ See, e.g., MYRON MAGNet, The Dream and THE Nightmare: The Sixties' Legacy to THe Underclass 188-94 (1993); Thomas Sowell, Preferential Policies: AN INTERNATIONAL PERSPECTIVE 103-15 (1990). 
known by the early 1970 s as affirmative action, would be heretofore rendered indistinguishable from the Old Despots, one and all "racist," "insensitive," and "Social Darwinist."

Spurred by the race riots of the 1960 s, urban policy observers smbraced the notion that metropolitan residential patterns resulting in local racial homogeneity was, at bottom, "segregation," and therefore an injustice leading to the violence. ${ }^{62}$ These warriors for equality either could not or would not discern between racial homogeneity resulting from coercion and racial homogeneity resulting from freedom of contract. The inadequacy of government response, its proponents argued more recently, precipitated the South Central Los Angeles riot of $1992 .{ }^{63}$

Strictly speaking, the New Despotism is socialism. But it is socialism of a sort that emerged in the 1960s. Its appeals are not to nationalization of banks and mines, nor to agricultural and industrial production targets, but to more public "compassion" in meeting human needs. Aggressively redistributionist, its proponents are impatient with present-day social and economic arrangements and proclaim that affluent citizens have a moral duty to pay for necessities of the less affluent. Paying for housing expenses, presumably to stabilize neighborhoods, is part of this shift in collective psychology of the Left, a shift in the state's underwriting of the economy from production to consumption.

In his tract, Equalizing People, ${ }^{64}$ English researcher and social philosopher David Green explains that socialists today, unlike those of bygone eras, admit that capitalism is the "goose that lays the golden egg. ${ }^{n 55}$ Yet they hasten to add that the distribution of the gold is unfair-that is, some individuals and groups inevitably will have far less than others. Thus, the state must maximize, within

${ }^{62}$ Recent examples of this position include MASSEY \& DENTON, supra note 13 , at 57-59 (noting that "economic deprivation, social isolation, and psychological alienation" were caused by years of segregation, which, in turn, sparked riots); GARY ORFIELD, HARVARD PROJECT ON SCH. DESEGREGATION, THE GROWTH OF SEGREGATION in American Schools: Changing Patterns of Separation and Poverty Since 1968 (1993).

${ }^{63}$ See Milton S. EISENhower Found., Investing in ChILDREN AND YOUTH, RECONSTRUCTING OUR CITIES: DOING WHAT WORKS TO REVERSE THE BETRAYAL OF AMERICAN DEMOCRACY 4-7 (1993); see also URBAN INST., CONFRONTING THE NATION'S URBAN CRISIS: FroM WATTS (1965) TO SOUTH CENTRAL LOS ANGELES (1992) (1992).

GA DAVID G. GREEN, INSTITUTE OF ECONOMIC AFFAIRS, EQUALIZING PEOPLE: WHY SOCIAL JUSTICE THREATENS LIBERTY (1990).

${ }^{65} I d$. at 2. 
reasonable limits, across-the-board equality. Arguing that this "middle way" is, in fact, socialism, he writes:

The new socialism ... no longer desires to use the power of the state to take direct control of industrial production; instead it hopes to use state power to equalize consumption. The socialist desire for material equality, not only remains, but is being repackaged and advocated with renewed vigour under the rallying cries of "citizenship," "social justice" and "positive freedom" ... . Few socialists aspire to bring about absolute equality; rather they believe there is a trade-off between equity and efficiency. ${ }^{66}$

Green further posits that "market competition" should be viewed in an overall societal context, not merely "as a device for creating wealth that can then be parcelled out in the political process. ${ }^{n 7}$

A "morally-responsible citizen" is a notion that the contemporary Left might see as "blaming the victim." But it is those on the Left, not its critics, who "play the race card," grossly magnifying the gravity of injustices committed by whites against blacks, while downplaying injustices committed by blacks (including those against other blacks) as products of a rigged incentive structure. It is they who believe implicitly that a poor person's potential to amass wealth necessarily precedes his virtue, rather than vice versa. Because the market cannot restrain those who fail to better the condition of the least well off in the act of bettering themselves, ${ }^{68}$ the task of guaranteeing justice falls upon the political process.

Grudgingly accepting the housing market's ability to create wealth, New Despots would use the power of the state to intervene in real estate investment decision-making to ensure that "underrepresented" populations receive their due. If such populations should lack the necessary purchasing power, Section 8 tenant assistance and other subsidies stand waiting in the wings. Treating people unequally under the law in order to produce equal results is, as Hayek has noted, the essence of collectivism. ${ }^{69}$ Under the new

${ }^{66} I d$.

${ }^{67} I d$.

${ }^{68}$ Egalitarians tend to argue that social inequality is morally justifiable, so long as market activity improves the welfare of the poorest as well as that of others. According to John Rawls, "[t]hose who have been favored by nature, whoever they are, may gain from their good fortune only on terms that improve the situation of those who have lost out." JOHN RAWLS, A THEORY OF JUSTICE 101 (1971).

${ }^{69}$ See F.A. HAYEK, THE CONSTTTUTION OF LIBERTY 85-87 (1960) (arguing that "[e]quality of the general rules of law and conduct . . . is . . . the only equality which we can secure without destroying liberty" and that coercing a more even distribution among members of society is to destroy a free society). 
rules, even behavior that unintentionally perpetuates inequality must be punished. Witness how under the Clinton Administration the Justice Department has strongarmed mortgage lenders into lowering standards of creditworthiness to boost approval rates for black applicants. Not wanting to be tagged with the stigma of "turning back the clock," opposition from New Despots usually have acquiesced.

Social justice, notes Norman Barry, rests on the assumption that only the state can produce it. ${ }^{71}$ Ironically, since being manifested in British policy, it has not only exacerbated the very inequality that it was intended to reduce, but has also dulled the altruistic impulses of citizens who are less than happy about being forced into a provider role. ${ }^{72}$ Marvin Olasky has recognized similar consequences of recent antipoverty policies in the United States. ${ }^{73}$

One reads in Schill and Wachter's article an endorsement, although somewhat muted, of this New Despotism. The authors fail to recognize either the limits of amelioration of inequality by the state or the dangers to individual liberty inherent in such an enterprise. What one gets from Schill and Wachter instead is an appeal to New Despots: "We agree with your goals, but we need a better focus and more thorough data before we can tax, spend, and regulate in the punitive manner that you wish." What the authors should be doing is challenging the very basis of this despotism and repudiating the legacy of the Kerner Commission report. They should be calling for resistance to egalitarian radicals who wear the clothing of "liberalism," whether they are government officials, nonprofit organizations, or academic researchers. They should be arguing against applying affirmative action-style criteria to real estate and mortgage finance transactions.

70 "Turning back the clock" is a dishonest and inflammatory metaphor, inasmuch as it equates opposition to a racial spoils system with social regression. When libertarians and conservatives say they want to eliminate government-mandated racial privileges, they are not wistfully seeking a return to Jim Crow days, but to the spirit of the 1964 Civil Rights Act, whose sponsors assured it would be race-neutral. Quite obviously, that legislation (especially Title VII) lacked the necessary safeguards to prevent its transformation into an instrument of political favoritism. It is New Despots, in reality, who are turning back the clock.

${ }^{71}$ See Norman P. Barry, The Philosophy of the Welfare State, 4 CRITICAL REv. 545, 563-66 (1990).

${ }^{72}$ See id. at $563-61$.

${ }^{73}$ See generally Marvin Olasky, The Tragedy of AmERican Compassion (1992). 


\section{CONCLUSION}

That the New Despotism in America thus far has done limited damage to metropolitan housing markets owes largely to mixed signals from the federal government. But having taken office in 1993, the Clinton Administration has given a clear signal that the time is ripe for letting a thousand lawsuits (or at least threats of lawsuits) bloom. It is difficult to imagine, even under the Carter Administration, a more ruthless pair of civil-rights enforcers than Roberta Achtenberg ${ }^{74}$ and Deval Patrick, officials bent on criminalizing transactions of banks and other financial intermediaries merely because certain ostensibly disadvantaged races or ethnic groups might benefit. We should be thankful for small miracles and "hysterical" conservatives for keeping the long-range goals of such officials and their supporters underfunded. It is to Schill and Wachter's credit that they recognize that federal efforts to reduce poverty, through well-meaning programs, laws, and court decisions, can instead create it. It is to the authors' debit, however, that they cannot bring themselves to debunk the welfare-state philosophy on which such follies rest.

${ }^{74}$ As of April 1995, Achtenberg appears headed out as HUD's Assistant Secretary for Fair Housing and Equal Opportunity; she reportedly plans to run for mayor of San Francisco. See Ruth Larson, HUD to Lose Top-Rank Official, WASH. TiMES, Apr. 5, 1995, at A12. 


\section{FROM THE EDITORS}

What follows is an abstract of Gary Orfield's article, Housing as a Justification for Resegregating Schools: Consequences of Changing Judicial Interpretations, presented at the University of Pennsylvania Law School as part of the Symposium printed in this issue. 